\title{
LACTATE DEHYDROGENASE ISOENZYME PATTERN IN TISSUES AND SERUM OF THE CALF
}

\author{
J. ŠALPLACHTA, J. NEČAS \\ Department of Biochemistry, Faculty of Veterinary Hygiene and Ecology, University of Veterinary and \\ Pharmaceutical Sciences, Brno, Czech Republic \\ Received January 26, 2000 \\ Accepted November 22, 2000 \\ Abstract \\ Šalplachta J., J. Nečas: Lactate Dehydrogenase Isoenzyme Pattern in Tissues and Serum of \\ the Calf. Acta vet. Brno 2000, 69: 267-275. \\ The aim of this study was to analyze the lactate dehydrogenase (LD) pattern in tissues and serum \\ of calves (Bohemian pied hybrids, with a substantial component of the Holstein breed) and \\ compared with data of similar studies. LD isoenzyme patterns were determined by polyacrylamide \\ gel electrophoresis, data were evaluated by current process and by a sum of vectors method (SV). \\ In the basic model SV5,LD(1-5), an evaluation of LD patterns as resultant vectors enabled an \\ easy detection of outlying data obtained in this study and those by others. It was found that calf \\ tissues under study differ substantially in their LD patterns. Comparing the angles SV[alpha] of \\ resultant vectors for our samples, we can state the following order: kidney $<$ left atrium $\approx$ right \\ atrium $<$ serum $<$ lung, spleen, liver $<<$ diaphragm. Calf tissues (lung, spleen, liver) differed in \\ $\mathrm{SV}$ [c] variable of resultant vector in the following order: lung $<$ spleen $<$ liver. No significant \\ differences between summer and winter serum LD patterns were found in contrast to literature data \\ obtained from cows kept under range conditions. This is necessary to consider when evaluating the \\ results of similar studies. \\ Polyacrylamide gel electrophoresis, healthy cattle, physiology
}

After proteosynthesis, H,M polypeptides of lactate dehydrogenase (LD, L-lactate:NAD oxidoreductase, EC 1.1.1.27) combine to form five tetrameric LD isoenzymes: LD1 (H4), LD2 (H3M), LD3 (H2M2), LD4 (HM3) and LD5 (M4). For separation of LD isoenzymes several electrophoretic techniques with different supporting media (cellulose acetate, agar, agarose, polyacrylamide) are currently applied. Eleven electrophoretic methods for quantifying LD isoenzymes in serum are compared in the study of Moses (1988). Tissue LD concentration is approximately 1000 times higher than LD concentration in serum or plasma, so that a leakage of LD from damaged cells is reflected in serum LD pattern. In medical research, changes of LD pattern in serum has been employed for detection of pathophysiological changes in the organism (Boyd 1982; Maekawa 1988; Pechová 1992; Rodrigue 1995).

LD isoenzyme patterns were currently evaluated using statistical analysis of single LD isoenzymes, ratios of $\mathrm{LD}$ isoenzymes and $\mathrm{H} / \mathrm{M}$ polypeptides until to the sum of vectors method (SV) became available. An application of the SV method makes the evaluation of several quantities possible and it offers a clear and workable information on LD patterns (Šalplachta 1997ab; Šalplachta 1998).

The purpose of the present study was to determine the LD pattern in the serum and tissues of healthy calves and to test its applicability on data from literature.

\section{Materials and Methods}

Lactate dehydrogenase and its isoenzymes were determined in the serum and tissues of calves (Bohemian pied hybrids, with a substantial component of Holstein). The determinations of LD and LD isoenzymes were carried out in serum of calves 3-3.5-months-old of both sexes and body weight approximately $100 \mathrm{~kg}$. The animals were conventionally reared on a farm in a loose-housing system.

Address for correspondence:

RNDr. Jan Šalplachta Ph.D.

Department of Biochemistry, Faculty of Veterinary Hygiene and Ecology

University of Veterinary and Pharmaceutical Sciences

Palackého 1-3, 6120 Brno, Czech Republic
Phone: +420541562510

Fax: +4205743020

http://www.vfu.cz/acta-vet/actavet.htm 
Tissue samples were taken from healthy 6-months-old calves immediately after slaughter in a slaugtherhouse (their average body weight was $210 \mathrm{~kg}$, they were fed a milk diet). Pending analysis, the tissues were stored in solid $\mathrm{CO}_{2}$. They were homogenized by high-speed blender Unipan 309 in a solution of $0.9 \% \mathrm{NaCl}, 5 \mathrm{mmol}$ TRIS-HCl $\mathrm{pH}$ 7.4. The extracts were collected after $30 \mathrm{~min}, 20^{\circ} \mathrm{C}, 15000 \times \mathrm{g}$ centrifugation and either immediately analysed or stored in solid $\mathrm{CO}_{2}$.

The total activity of LD in the sample was determined by photometrical method with iodonitrotetrazolium violet (Bio-La-test Lactate dehydrogenase, Lachema, Czech Republic).

To obtain LD isoenzyme patterns, conventional polyacrylamide gel electrophoresis ( $3 \mathrm{~mm}$ inner diameter, $5 \mathrm{~cm}$ length of gel) were carried out. Buffer TRIS-HCl $(0.1 \mathrm{~mol} / \mathrm{l}) \mathrm{pH} 8.6$ was in $5.5 \%$ polyacrylamide gel, electrode spaces and deposited sample. Electrophoresis lasted for $70 \mathrm{~min}$ with the voltage of $25 \mathrm{~V} / \mathrm{cm}$ and the temperature was $10^{\circ} \mathrm{C}$. Van der Helm's staining solution modified with $\mathrm{NaCl}$ instead of $\mathrm{NaCN}$ was used (Dietz and Lubrano 1967 ) with composition: $0.1 \mathrm{~mol} / \mathrm{l}$ of sodium lactate, $1.5 \mathrm{mmol} / 1$ of NAD, $0.1 \mathrm{~mol} / 1 \mathrm{TRIS}-\mathrm{HCl} \mathrm{pH} 8.6,10 \mathrm{mmol} / 1 \mathrm{of}$ sodium chloride and $5 \mathrm{mmol} / \mathrm{l}$ magnesium chloride. The staining solution contained in $10 \mathrm{ml} 0.3 \mathrm{mg}$ of phenazinmethosulphate and $2.5 \mathrm{mg}$ nitrobluetetrazolium. After $30 \mathrm{~min}$ staining at $30^{\circ} \mathrm{C}$, the gels were transferred into a solution of acetic acid $(70 \mathrm{ml} / \mathrm{l})$. Formazane zones were quantified by a Beckman CDS 200 densitometer. All used reagents were of analytical grade and distilled water was used.

The sum of vectors method (SV): LD isoenzyme patterns were converted to the resultant vectors of basic model SV5,LD(1-5) under conditions described in detail elsewhere (Šalplachta 1997). The basic model SV5,LD(1-5) uses a two-dimensional system of rectangular axes $\mathrm{x}, \mathrm{y}$ in the plane in which LD isoenzymes are represented with constituent vectors starting in the point of intersection of axes. By summation of all constituent vectors every resultant vector is determined so that an end point of resultant vector represents its LD pattern. The end point variables SV5[x;y] of resultant vector were used to create the graphical presentation of the results and for statistic evaluation.

A theoretical vector was calculated for the resultant vector derived from experimental LD pattern in tissue and both vectors have the same orientation (Šalplachta 1998). Theoretical resultant vector represents a theoretical LD pattern resulting from random association of H,M polypeptides. The end point variables SV5[alpha;c] of resultant vector were applied to compare the data presented in this study and those published by other authors (Prasse 1969; Keller and Stanbridge 1972; Keller 1974; Lauerman et al. 1978; Jain and Bike 1985; Yasuda et al. 1989; Heinová and Blahovec (1994). Statistical analysis was performed by F-test and Student's $t$-test.

\section{Results}

Summer and winter LD isoenzyme pattern in calf serum

Serum samples were taken in August and in January. Mean isoenzyme LD patterns and mean total LD activities in serum are given in Table 1.

Table 1

Isoenzyme L-lactate dehydrogenase patterns and total LD activity in calf serums taken in summer and winter are presented. The end point data of resultant vectors computed in basic model SV5,LD (1-5) are added.

\begin{tabular}{|c|c|c|c|c|c|c|c|c|c|c|}
\hline \multirow{2}{*}{$\begin{array}{c}\text { August } \\
\mathrm{n}=14\end{array}$} & LD 1 & LD 2 & LD 3 & LD 4 & LD 5 & LDtot & SV[alfa] & $\mathrm{SV}[\mathrm{c}]$ & $\mathrm{SV}[\mathrm{x}]$ & $\mathrm{SV}[\mathrm{y}]$ \\
\hline & & & & & & & & & \multicolumn{2}{|c|}{ 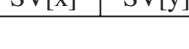 } \\
\hline Mean & 34.2 & 35.8 & 22.5 & 5.8 & 1.7 & 7026 & 97.8 & 48.2 & -6.4 & 47.6 \\
\hline $\mathrm{s}$ & 2.5 & 1.1 & 2.1 & 1.2 & 0.6 & 798 & 4.8 & 2.9 & 3.6 & 3.4 \\
\hline \multicolumn{11}{|l|}{$\begin{array}{c}\text { January } \\
\mathrm{n}=12\end{array}$} \\
\hline Mean & 33.7 & 34.8 & 24.9 & 4.4 & 2.2 & 11159 & 99.8 & 48.3 & -8.0 & 47.4 \\
\hline $\mathrm{s}$ & 3.3 & 1.6 & 2.1 & 1.4 & 1.0 & 1493 & 5.7 & 3.9 & 4.4 & 4.4 \\
\hline
\end{tabular}

Relative LD isoenzyme activity is presented; total L-lactate dehydrogenase activity is expressed as [nkat/l]. End point of resultant vector is specified co'ordinate variables SV[x], SV[y] or vector angle SV[alfa] and vector value $\mathrm{SV}[\mathrm{c}]$. SV ... sum of vectors method; s ... standard deviation; $\mathrm{n}$... number of calves.

The resultant vectors of LD isoenzyme patterns were calculated in the basic model SV5,LD(1-5) to demonstrate a distribution of LD patterns in serum. The data (January) are shown in Fig. 1.

The variables SV $[\mathrm{x} ; \mathrm{y}]$ of resultant vectors were tested by two-tailed F-test $(P<0.05)$. We state that there is insufficient evidence to conclude that the variances are not the same. Based on the two-tailed $t$-test $(\mathrm{P}<0.05)$, we also state that there is insufficient evidence to conclude 
that the means are not the same. It can be stated, that no significant differences between summer and winter serum LD isoenzyme patterns were found.

LD isoenzyme pattern in calf tissues

LD isoenzyme pattern of calf tissues are presented in Table 2, and their resultant vectors are shown in Figs. 1-3, 5 to demonstrate the distribution of LD patterns in tissues. Mean resultant vector is equipped with rectangle and its corner points are defined by the equations: $\mathrm{SV}[\mathrm{x}] \pm 2 \mathrm{~s}[\mathrm{x}] ; \mathrm{SV}[\mathrm{y}] \pm 2 \mathrm{~s}\left[{ }_{\mathrm{y}}\right]$. A rectangle area contains an end point of resultant vector whose LD pattern is in the reference interval of a healthy population with $95 \%$ probability. Outlying LD patterns were detected. The most differing LD pattern was omitted in some tissue data files and corresponding rectangles were calculated. LD isoenzyme data are presented in Table 2. and rectangles are indicated by a dotted line in Figs. 1-3. As a percentage of rectangle area from all samples, the analogous areas are: right atrium $73 \%$, left atrium $34 \%$, spleen $27 \%$, lung 57\%, liver $49 \%$, and diaphragm $64 \%$. Serum and kidney data file were not recalculated. We did not continue the statistic analysis because of the small number of calves in experiment. The evaluation of LD patterns by evaluation of theirs vectors in basic model SV5,LD(1-5), enables an easier detection of outlying LD patterns than up to now used statistic analysis of five LD isoenzymes.

Table 2

The mean LD pattern in tissues of healthy calves. The end points of resultant vectors vere calculated from LD patterns in basic model SV5, LD (1-5). All data are presented as mean $\pm \mathrm{s}$.

\begin{tabular}{|c|l|l|c|c|c|c|c|c|c|}
\hline $\mathrm{n}=10$ & LD 1 [\%] & LD 2 [\%] & LD 3 [\%] & LD 4 [\%] & LD 5 [\%] & SV [alfa] & SV [c] & SV [x] & SV [y] \\
\hline Kidney & $53.5 \pm 2.5$ & $29.6 \pm 1.7$ & $11.2 \pm 1.3$ & $4 \pm 1$ & $1.7 \pm 0.6$ & $67.2 \pm 2.9$ & $59.6 \pm 3.3$ & $23.2 \pm 3.4$ & $54.8 \pm 2.9$ \\
\hline Atrium left & $42.1 \pm 6.1$ & $39.7 \pm 2.6$ & $13 \pm 3.6$ & $3.5 \pm 1.7$ & $1.6 \pm 0.9$ & $81.9 \pm 8.4$ & $59.4 \pm 6.5$ & $9 \pm 8.5$ & $58.2 \pm 5.9$ \\
\hline Atrium right & $39.2 \pm 4.1$ & $38.5 \pm 1.1$ & $15.9 \pm 1.9$ & $4.6 \pm 1.2$ & $1.9 \pm 0.6$ & $86.1 \pm 5.5$ & $54.5 \pm 1.0$ & $4.0 \pm 5.4$ & $54.1 \pm 3.4$ \\
\hline Lung & $23.5 \pm 2.8$ & $27.2 \pm 2.5$ & $23 \pm 1.9$ & $14.4 \pm 1$ & $11.8 \pm 2.7$ & $113.2 \pm 13.8$ & $20.7 \pm 4.7$ & $-7.3 \pm 2$ & $19 \pm 5.7$ \\
\hline Spleen & $22.2 \pm 2.3$ & $29.3 \pm 1.1$ & $24.5 \pm 1.6$ & $14.8 \pm 0.9$ & $9.2 \pm 1$ & $120.9 \pm 9.2$ & $25.2 \pm 2.1$ & $-12.6 \pm 2.7$ & $21.4 \pm 3.6$ \\
\hline Liver & $22.3 \pm 3.5$ & $33.2 \pm 1.8$ & $27.7 \pm 1.4$ & $12.4 \pm 2$ & $4.4 \pm 1.4$ & $124.3 \pm 8.9$ & $36.9 \pm 3.8$ & $-20.2 \pm 3.6$ & $30.4 \pm 5.9$ \\
\hline Diaphragm & $14.6 \pm 2.7$ & $12.7 \pm 1.4$ & $16.4 \pm 1.9$ & $18.6 \pm 1.3$ & $37.7 \pm 4.7$ & $310.6 \pm 7.3$ & $25.4 \pm 6.5$ & $16.3 \pm 4.6$ & $-19.2 \pm 5.7$ \\
\hline
\end{tabular}

\begin{tabular}{|c|l|l|l|c|c|c|c|c|c|}
\hline $\mathrm{n}=9$ & LD 1 [\%] & LD 2 [\%] & LD 3 [\%] & LD 4 [\%] & LD 5 [\%] & SV [alfa] & SV [c] & SV [x] & SV [y] \\
\hline Atrium left & $43.4 \pm 4.7$ & $40.2 \pm 2.2$ & $12.1 \pm 2.2$ & $3.1 \pm 0.8$ & $1.4 \pm 0.4$ & $80.1 \pm 6.1$ & $61.3 \pm 2.9$ & $10.7 \pm 6.7$ & $60 \pm 2.3$ \\
\hline Atrium right & $38.3 \pm 3.1$ & $38.7 \pm 0.8$ & $16.2 \pm 1.6$ & $4.8 \pm 1$ & $1.9 \pm 0.5$ & $87.2 \pm 4.3$ & $53.8 \pm 3.1$ & $2.9 \pm 4$ & $53.6 \pm 3$ \\
\hline Lung & $24.2 \pm 1.6$ & $27.7 \pm 2$ & $22.8 \pm 1.7$ & $14.2 \pm 0.6$ & $11.1 \pm 1.5$ & $109.2 \pm 5.5$ & $21.8 \pm 2.9$ & $-7.1 \pm 0.9$ & $20.5 \pm 2.5$ \\
\hline Spleen & $22.9 \pm 1.1$ & $29.5 \pm 0.9$ & $24 \pm 0.5$ & $14.6 \pm 0.8$ & $9 \pm 0.8$ & $118.3 \pm 3.8$ & $25.2 \pm 2.1$ & $-11.8 \pm 0.9$ & $22.2 \pm 2.5$ \\
\hline Liver & $21.4 \pm 2$ & $33.3 \pm 1.8$ & $28.1 \pm 1$ & $12.7 \pm 1.8$ & $4.6 \pm 1.2$ & $126.3 \pm 6.2$ & $36.5 \pm 3.6$ & $-21.2 \pm 1.8$ & $29.5 \pm 5.2$ \\
\hline Diaphragm & $14.9 \pm 2.6$ & $12.8 \pm 1.3$ & $16.8 \pm 1.5$ & $18.8 \pm 1.1$ & $36.7 \pm 3.4$ & $310 \pm 7$ & $24.1 \pm 5.2$ & $15.2 \pm 2.9$ & $-18.5 \pm 5.2$ \\
\hline
\end{tabular}

Data file with 9 calves arose from data file of 10 calves minus one the most distinct LD pattern. SV ... the metod of vectorisation and of summation of biochemical quantity vectors. s ... standard deviation. Variables SV [alpha, c] or $\mathrm{SV}[\mathrm{x}, \mathrm{y}]$, specify the end point position of vector. SV [alpha, c] are vector quantities angle and value; SV $[\mathrm{x}, \mathrm{y}]$ are co'ordinates in axes $\mathrm{x}, \mathrm{y}$.

It was found that calf tissues differ significantly in LD patterns. Comparing a ratio (experimental SV[c]/theoretical SV[c]), the following order was created: diaphragm $<$ lung $<$ spleen $<$ liver $<$ kidney $<$ right atrium $\approx$ left atrium.

\section{Discussion}

A comparison of mean LD patterns obtained in this study with those published by other investigators for serum or tissue has been made by comparison of resultant vectors in basic model SV5,LD(1-5). Data files taken from literature are presented in Table 3 and Figs. 4, 5. 


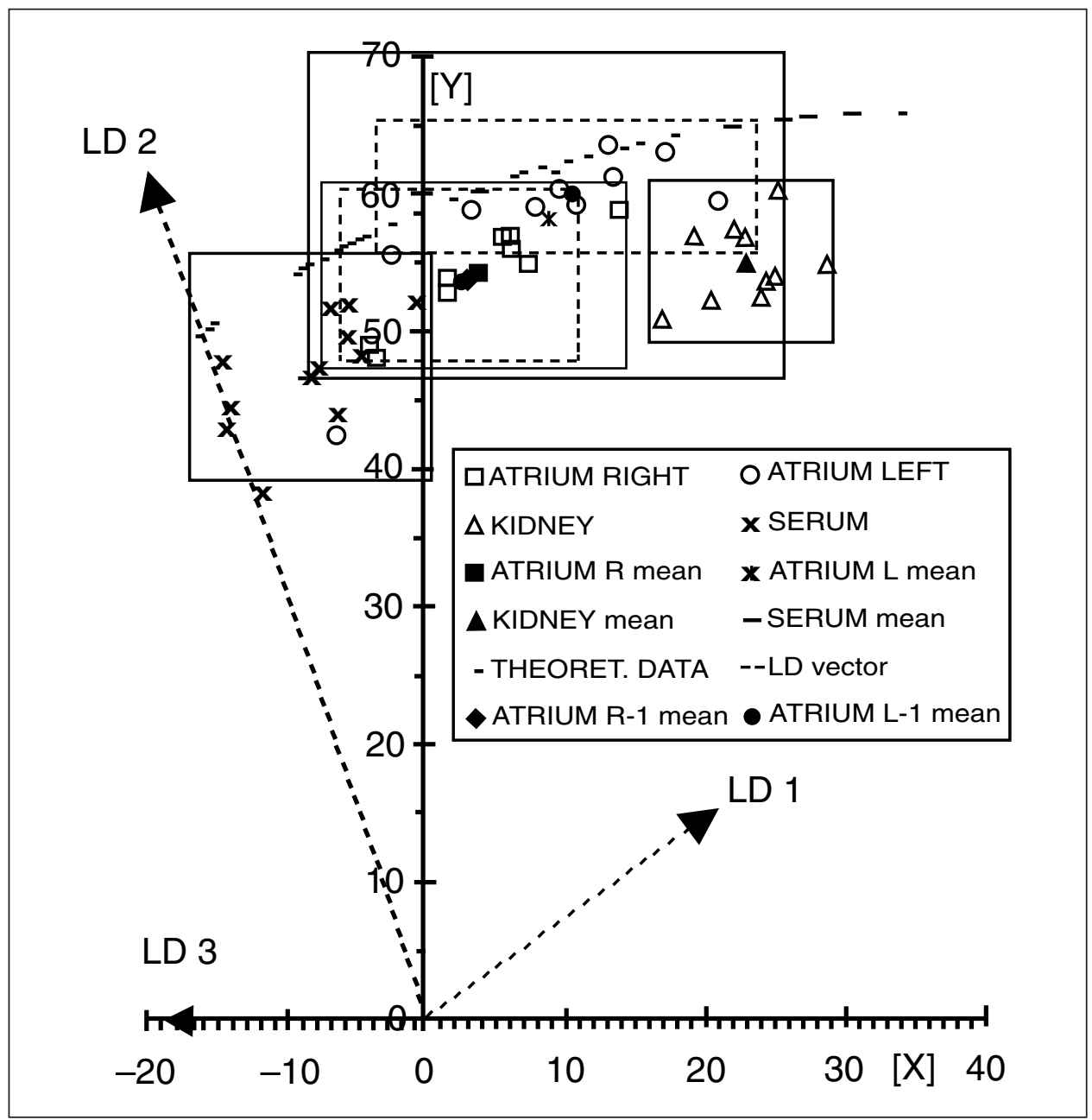

Fig.1. The LD isoenzyme pattern of calf tissues ( 10 calves) and serum (January, 12 calves) are expressed as the end points of resultant vectors in basic model SV5,LD(1-5).

LD pattern in serum

The analysis of serum data indicates a good concord between the vectors of this study in calves and those in nonpregnant dairy cows, aged 2 to 5 years and 5 steers aged 1 to 2 years (Keller 1974). Moreover, both are very close to data from the study by Prasse (1969). A clear difference has been found between data of the previous three studies and the data from Jain and Bike (1985), Lauerman et al. (1978) and Heinová and Blahovec (1994). The difference cannot be explained by different age of experimental animals. It is more likely that the differences in analytical methods, breed and in management between dairy cattle and feedlot cattle are expressed. The results of study Avallone (1996) indicate the increases of angle SV[alpha] of resultant vector where as vector variable SV[c] is nearly constant at ages ranging from 2 to 10 weeks. Data are not shown in this paper. The study of 


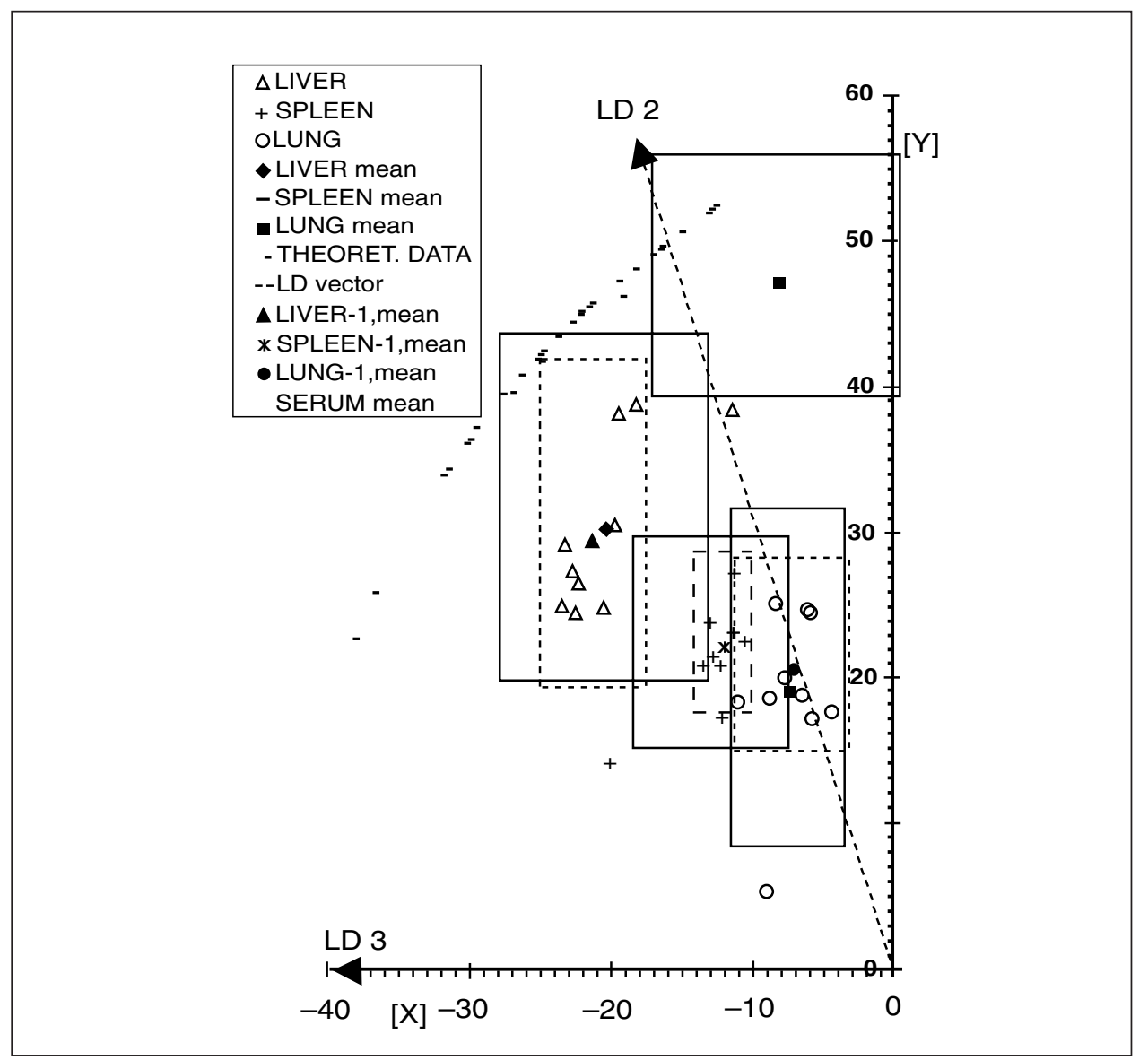

Fig.2. The LD isoenzyme pattern of calf tissues (10 calves) and serum (January, 12 calves) are expressed as the end points of resultant vectors in basic model SV5,LD(1-5)

Prasse (1969) indicates that with advancing age of cattle the angle SV[alpha] of resultant vector decreases whereas the vector variable SV[c] is nearly constant (ages 1 to 6 years). On the other hand, summer/winter seasonal changes in plasma LD pattern of cows under range conditions are characterized by change of vector variable SV[c] whereas the angle $\mathrm{SV}$ [alpha] is nearly constant (Jain and Bike 1985).

\section{LD pattern in tissues}

The theoretical LD pattern is based on hypothesis LD tetramer is assembled from four randomly selected H,M polypeptides (Emery 1967). A cell population and its heterogenity from which $\mathrm{LD}$ was released into serum can be estimated by $\mathrm{P}_{\mathrm{M}}$ model distribution (Feldman 1983). We assume that the more the theoretical and experimental vector variable SV[c] differ the broader is the distribution of cell population in LD pattern. However, other mechanisms (non-random association LD tetramers, degradation of isoenzymes, pathological sample, analytical assessment) may be involved in the creation of LD pattern. It was found that calf diaphragm has the most differring, and calf heart has the least differring LD pattern from the theoretical LD pattern. It has been found that every 
Table 3

The LD isoenzyme pattern of bovine serum and tissues from the literature: $\mathrm{P}=$ Prasse 1969, K = Keller 1972 and 1974, L = Lauerman 1978, J = Jain 1985, Y = Yasuda 1989 and H = Heinová 1994. The end points of resultant vectors were calculated from LD patterns in basic model SV 5, LD (1-5).

\begin{tabular}{|lccccccccc|}
\hline Paper/sample & LD 1 & LD 2 & LD 3 & LD 4 & LD 5 & SV [alpha] & SV [c] & SV [x] & SV [y] \\
\hline L. serum & 36.5 & 24.7 & 16.9 & 12.0 & 9.1 & 72.9 & 29.7 & 8.7 & 28.4 \\
J. serum Jan & 46.0 & 27.0 & 16.5 & 5.2 & 3.6 & 73.3 & 48.5 & 13.9 & 46.4 \\
J. serum Mar & 52.1 & 27.0 & 13.5 & 3.2 & 2.8 & 67.9 & 56.4 & 21.2 & 52.3 \\
J. serum Jun & 43.0 & 25.0 & 16.1 & 7.6 & 6.3 & 70.2 & 41.3 & 14.0 & 38.9 \\
J. serum Jul & 40.0 & 24.0 & 16.5 & 9.1 & 9.6 & 67.3 & 35.0 & 13.5 & 32.3 \\
J. serum Nov & 51.0 & 25.0 & 14.6 & 4.9 & 2.4 & 67.9 & 52.6 & 19.8 & 48.7 \\
K. serum & 36.5 & 32.7 & 22.0 & 5.8 & 3.0 & 92.5 & 45.3 & -1.9 & 45.3 \\
P. serum I. & 31.6 & 29.8 & 23.8 & 9.8 & 4.8 & 100.7 & 35.5 & -6.6 & 34.8 \\
P. serum II. & 34.1 & 27.7 & 21.8 & 9.7 & 6.3 & 91.2 & 33.6 & -0.7 & 33.6 \\
P. serum III. & 37.3 & 28.4 & 20.2 & 9.1 & 4.9 & 86.4 & 37.5 & 2.4 & 37.4 \\
H. serum & 53.0 & 35.0 & 11.0 & 1.0 & 0.0 & 71.9 & 66.8 & 20.8 & 63.5 \\
K. heart & 41 & 38 & 20 & 1 & 0 & 88.9 & 59.3 & 1.1 & 59.3 \\
K. muscle & 4 & 8 & 10 & 22 & 56 & 303.7 & 52.7 & 29.3 & -43.9 \\
K. kidney & 72 & 28 & 0 & 0 & 0 & 54.3 & 84.9 & 49.6 & 69.0 \\
K. spleen & 42 & 38 & 16 & 4 & 0 & 85.5 & 57.2 & 5.0 & 57.0 \\
K. brain & 49 & 29 & 21 & 1 & 0 & 80.4 & 56.2 & 9.4 & 55.4 \\
K. liver & 40 & 39 & 16 & 5 & 0 & 87.2 & 55.9 & 2.8 & 55.8 \\
Y. liver & 31.7 & 24.8 & 27.3 & 12.8 & 3.3 & 110.7 & 30.1 & -10.6 & 28.1 \\
\hline
\end{tabular}

Relative LD isoenzyme activity is presented. SV ... sum of vectors metod.

The end point of resultant vector is specified co' ordinate variables SV [x], SV [y], basic method SV 5, LD (1-5).

P. serum ... the age of dairy cattle group I. (6-18 mon.), II. 2-5 year, III. 6+ year.

resultant vector with exception of that derived from LD pattern in the kidney (Keller and Stanbridge 1972) is smaller than its theoretical vector. This fact calls for additional investigation.

Comparing the angles SV[alpha] of resultant vectors for calf samples, we found the following order: kidney $<$ left atrium $\approx$ right atrium $<$ serum $<$ lung, spleen, liver $<<$ diaphragm. The lung, spleen, liver differed in SV[c] variable of resultant vectors creating an

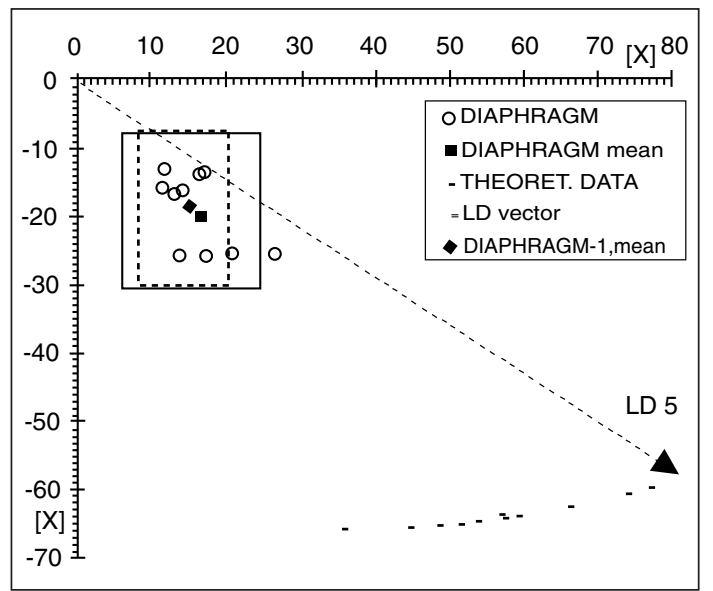

Fig.3. The isoenzyme LD pattern of calf diaphragms ( 10 calves) are expressed as the end points of resultant vectors in basic model SV5,LD(1-5). order lung < spleen < liver. Analogous data from the study of Keller and Stanbridge (1972) gave following order of the angles SV[alpha]: kidney $<<$ brain, spleen, liver, heart $<<$ muscle. By SV[c] variable comparison, we did not found significant differences between the tissues (brain, spleen, liver, heart) from the study by Keller and Stanbridge (1972). The vector discrepancy of LD patterns in liver, spleen and kidney of this study and that of Keller and Stanbridge (1972) might be explained by different age of the animals, however, other explanation cannot be excluded. The resultant vectors derived from the LD pattern in heart are nearly identical for 


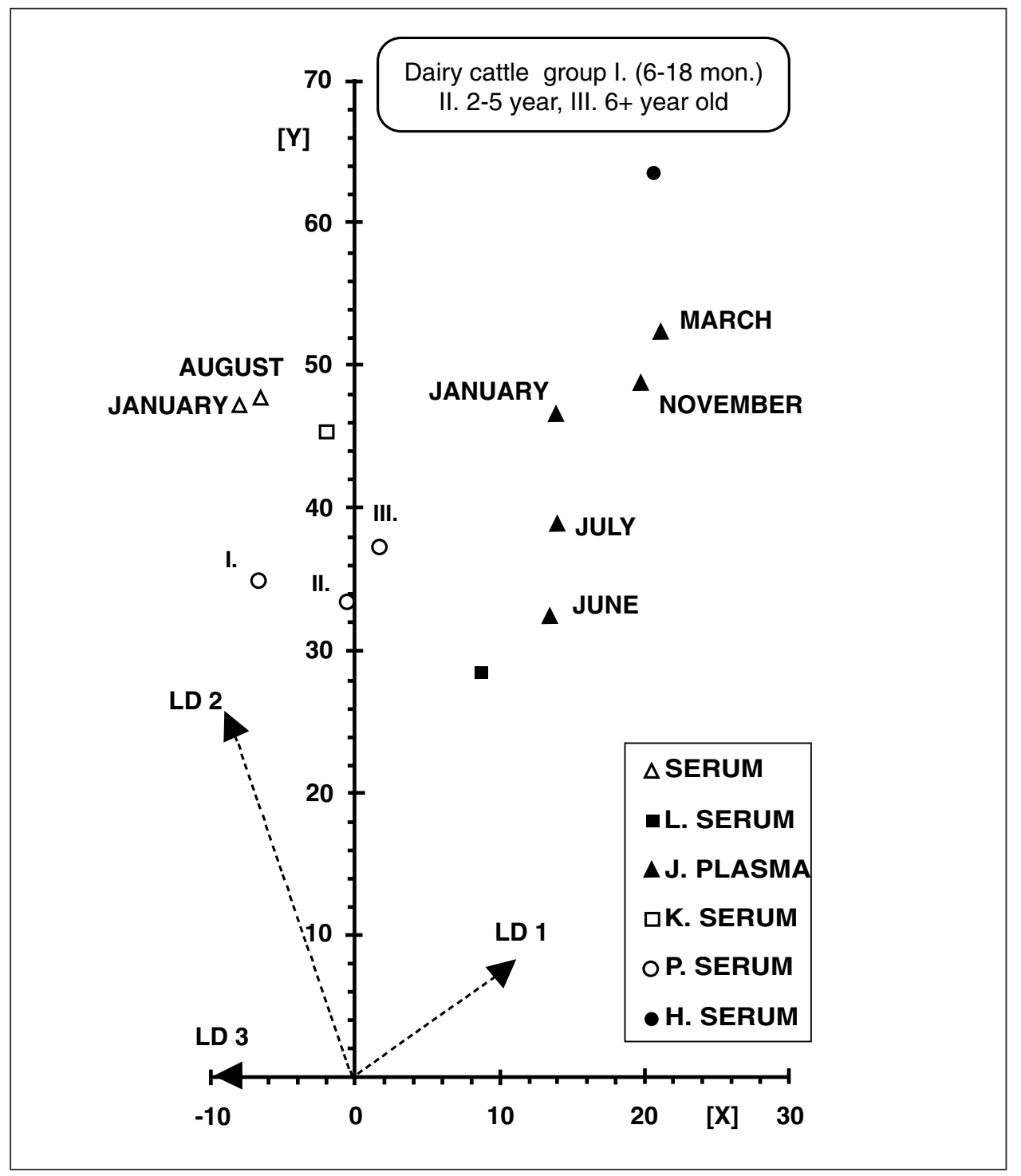

Fig.4. The LD isoenzyme pattern of bovine serum/plasma from this study and literature (P= Prasse 1969, K= Keller 1974, L = Lauerman 1978, J = Jain 1985, H = Heinová 1994) as the end points of resultant vectors in basic model SV5,LD(1-5).

the data from this study and that of Ke lle r (1972). A similar situation was with the vectors of liver LD patterns from this study and from the paper by Y a s u d a et al. (1989).

In conclusion, the SV method enabled a clearer, more detailed and simpler inspection and evaluation of data files and their comparison than currently used statistical analyses of five LD isoenzymes piece by piece. We can thus easily differentiate calf tissues by their LD patterns. We expect that the presented data and the evaluation method may be successfully used for more detailed evaluation of enzyme patterns in similar studies. 


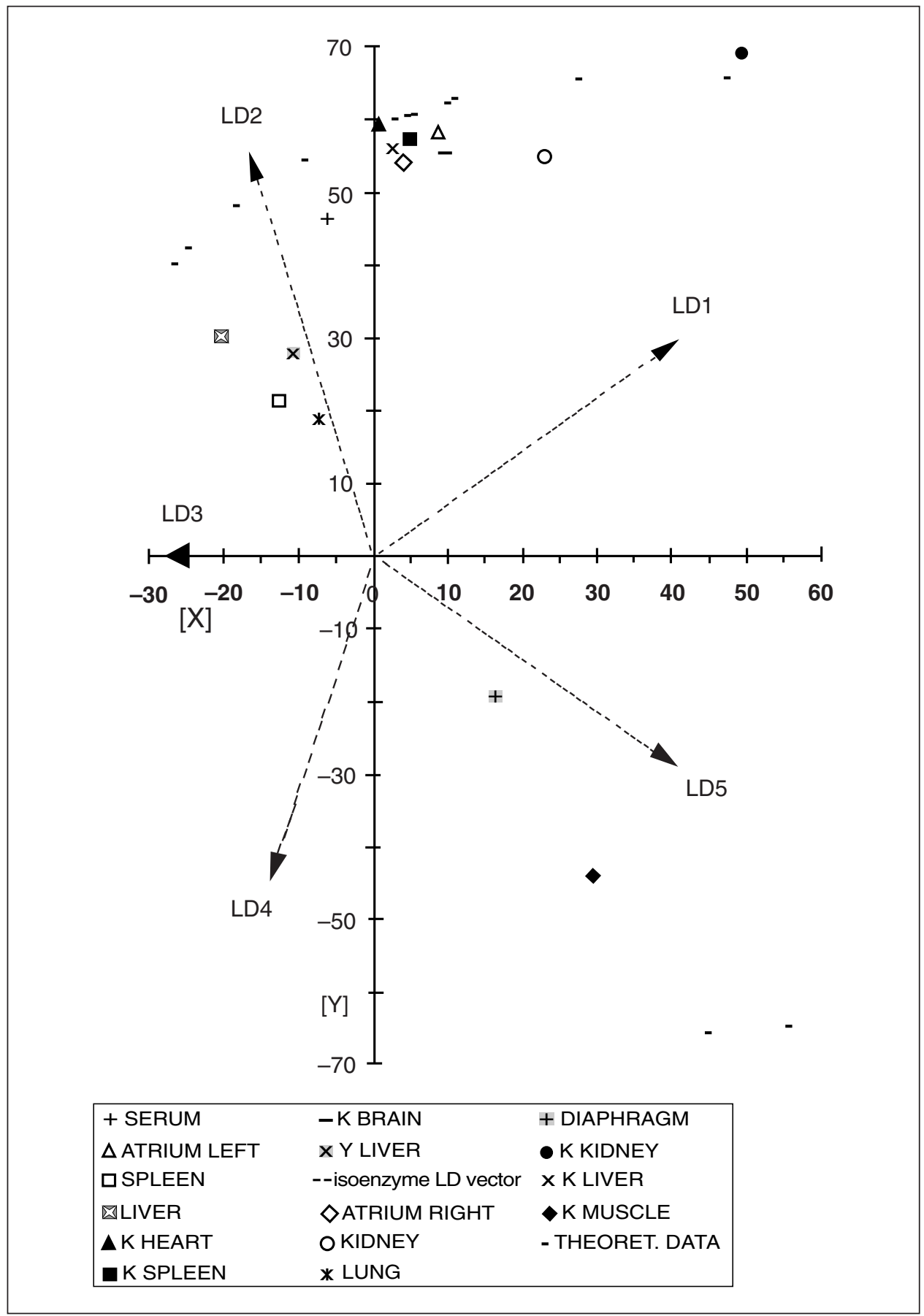

Fig.5. The LD isoenzyme pattern of bovine serum and tissues from this study and literature ( $\mathrm{K}=$ Keller 1972 and $1974, \mathrm{Y}=$ Yasuda 1989) as the end points of resultant vectors in basic model SV5,LD(1-5). 


\section{Isoenzymové složení laktátdehydrogenasy v séru a tkáních telat}

Cílem této práce bylo získat hodnoty složení laktátdehydrogenasy z tkání a séra telat (hybrid Český červenostrakatý se značnou složkou Holstein) a jejich srovnání s daty z podobných studií. Isoenzymové složení laktátdehydrogenasy bylo stanoveno metodou polyakrylamidové elektroforézy, data byla vyhodnocena jak běžným postupem, tak metodou součtu vektorů (SV).

Hodnocení LD složení jako výsledného vektoru v základnim modelu SV5,LD(1-5) umožnilo snadnou identifikaci odlehlých hodnot stejně jako snadné srovnání dat z této studie s literárními údaji. Bylo zjištěno, že se složení LD zkoumaných vzorků významně liší. Pro naše vzorky jsme vytvořili po srovnání úhlů $S V$ [alpha] vektorů následující pořadí: ledvina $<$ levé atrium $\approx$ pravé atrium $<$ sérum $<$ plíce, slezina, játra $<<$ bránice. Tkáně telat (plíce, slezina, játra) se liší v hodnotách proměnné $S V[c]$ v pořadí: plíce < slezina < játra. Nebyly zjištěny významné rozdíly v LD složení séra odebraného v létě nebo v zimě na rozdíl od literárních dat (krávy chované na pastvině). Tuto skutečnost je nezbytné brát v úvahu při hodnocení dat z podobných studií.

\section{References}

AVALlONE, L., LOMBARDI, P., FLORIO, S., d'ANGELO, A., BOGIN, E. 1996: Age-dependent variations of lactate dehydrogenase and creatine kinase activities in water buffalo calf serum. Eur. J. Clin. Chem. Clin. Biochem. 34: 961-964

BOYD, J. W. 1982: The mechanisms relating to increases in plasma enzymes and isoenzymes in diseases of animals. Vet. Clin. Path. 12: 9-24

DIETZ, A. A., LUBRANO, T. 1967: Separation and quantitation of lactic dehydrogenase isoenzymes by disc electrophoresis. Anal. Biochem. 20: 246-257

EMERY, A. E. H. 1967: The determination of lactate dehydrogenase isoenzymes in normal human muscle and other tissues. Biochem. J. 105: 599-604

FELDMAN, H. A. 1983: The PM distribution: a model for interpreting LD isoenzyme patterns. Clin. Chim. Acta 135: $109-134$

HEINOVÁ, J., BLAHOVEC, J. 1994: Izoenzýmy laktátdehydrogenázy v cicavčích a kuracích sérach. Vet. Med. - Czech 39: 75-84

JAIN, A. K., BIDE, R. W. 1985: Seasonal changes in the plasma isoenzymes of lactate: NADH oxidoreductase in Hereford cows under range conditions. Comp. Biochem. Physiol. 82B: 837-839

KELLER, P. 1974: Lactate dehydrogenase isoenzymes in normal bovine serum and during experimental liver and muscle damage. Res. Vet. Sci. 17: 49-58

KELLER, P., STANBRIDGE, T. A. 1972: Die Verteilung der Lactat-Dehydrogenase-Isoenzyme in Einigen Rinderorganen. Schweiz. Arch. Tierheilk. 115: 35-48

LAUERMAN, L. H., RUPPANNER, R., NORMAN, B. B., ADAMS, C. J. 1978: Metabolic and cellular profile testing in calves under feedlot conditions: Lactate dehydrogenase isoenzymes - reference values. Am. J. Vet. Res. 39: 855 - 857

MAEKAWA, M. 1988: Lactate dehydrogenase isoenzymes. J. Chromatogr. 429: 373-398

MOSES, G. C., ROSS, M. L., HENDERSON A. R. 1988: Ten electrophoretic methods compared with a selected method for quantifying lactate dehydrogenase isoenzymes in serum. Clin. Chem. 34: 1885-1890

PECHOVÁ, A. 1992: Diagnostika a prevence lipomobilizačního syndromu u dojnic v poporodním období. CSc.Thesis, Univ.Vet. Pharm. Sci., Brno, 170 p.

PRASSE, K. W. 1969: Lactic dehydrogenase activity and isoenzyme distribution in serum of normal cattle. Am. J. Vet. Res. 30: 2181-2184

RODRIGUE, F., BOYER, O., FEILLET F., LEMONNIER A. 1995: Lactate dehydrogenase LD5:LD2 ratio as an indicator of early graft function and complications following pediatric orthotopic liver transplantation. Transplant. Proc. 27: 1871-1874

ŠALPLACHTA, J. 1997a: The sum of vectors method (SV) applied to the lactate dehydrogenase isoenzymes and the creatine kinase isoforms. Clin. Chim. Acta 259: 51-71

ŠALPLACHTA, J. 1997b: Metoda součtu vektorů (SV) a její aplikace na isoenzymy laktátdehydrogenasy a kreatinkinasy. (The method of summation of vectors $(\mathrm{SV})$ and its application to lactate dehydrogenase and creatine kinase isoenzymes) Ph.D. Thesis, Univ. Vet. Pharm. Sci., Brno, 114 p.

ŠALPLACHTA, J. 1998: Tissue LD isoenzyme pattern and two sorts of theoretical LD isoenzyme patterns. Chem. Papers 52: 343

YASUDA, J., SYUTO, B., TOO, K., OHFUJI, S. 1989: Lactate dehydrogenase isoenzymes in bovine liver tissue. Jap. J. Vet. Sci. 51: 733-739 